\title{
Diet of the introduced Gough Moorhen Gallinula comeri on Tristan da Cunha
}

\section{Den introducerade goughrörhönans Gallinula comeri diet på Tristan da Cunha}

\author{
Alexander L Bond ${ }^{1,2}$ (iD) \& Gregory TW McClelland ${ }^{1,3}$ \\ ${ }^{1}$ RSPB Centre for Conservation Science, Royal Society for the Protection of Birds, The Lodge, Sandy Bedfordshire, SG19 \\ 2DL, United Kingdom ${ }^{2}$ Current address: Bird Group, Department of Life Sciences, The Natural History Museum, Akeman \\ Street, Tring, Hertfordshire, HP23 6AP, United Kingdom | a.bond@nhm.ac.uk ${ }^{3}$ Current address: Canadian Wildlife \\ Service, Environment and Climate Change Canada, 5421 Robertson Road, Delta, British Columbia, V4K 3N2, Canada | \\ gregory.mcclelland@canada.ca
}

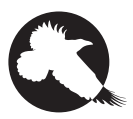

GOUGH MOORHENS Gallinula comeri were introduced to Tristan da Cunha in the 1950s, and are now numerous in lowland habitat, filling the ecological niche of the extinct Tristan Moorhen G. nesiotis. On their native Gough Island, moorhens have a varied diet, ranging from vegetation and fruits to scavenging and even predatory behaviour. Here, we examined the stomach contents of four birds on Tristan da Cunha to provide insight into their diet. Moorhens mostly ate vegetation, but we also recorded spiders (Arthropoda: Aranea), earthworms (Oligochaeta: Lumbricidae), remains of introduced rodents (Mus musculus), and anthropogenic debris. As on Gough Island, moorhens on Tristan have a generalist diet, and the impact of ecosystem restoration (and of the moorhens themselves) should be considered.

Keywords: predation | scavenging | generalism | endemic species | island | South Atlantic Ocean

Tristan da Cunha $\left(37^{\circ} 7^{\prime} \mathrm{S}, 12^{\circ} 18^{\prime} \mathrm{W}\right)$ and its associated islands (Nightingale, Inaccessible, and Gough islands; Figure 1) are among the most remote in the world, and consequently have a high number of endemic species (Wace \& Holdgate 1958, Holdgate 1965, Wace \& Dickson 1965). Tristan is home to c. 250 residents, and is nearly circular, covering $96 \mathrm{~km}^{2}$ with the conical Queen Mary's Peak rising $2060 \mathrm{~m}$. Of all the islands in the group, Tristan is geologically the most recent and only 0.2-0.5 million years old (Ryan 2007). Since human settlement in the early $19^{\text {th }}$ century, an increasing number of introduced and invasive species have arrived on the 


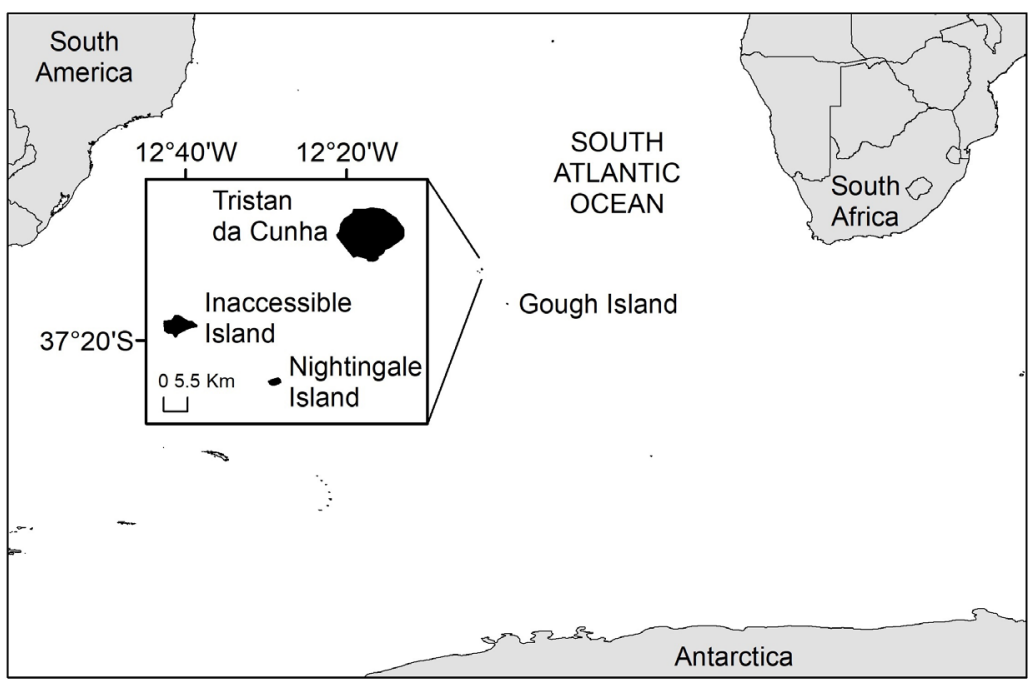

FIGURE 1. The location of Tristan da Cunha and Gough islands in the South Atlantic Ocean. The map is shown in Mercator projection.

- Tristan da Cunha och Gough är belägna mitt i Sydatlanten. Kartan visas i Mercators projektion. likely as a result of predation by introduced cats Felis catus (eradicated in the early 1970s) and human persecution (Sperling 1872, Richardson 1984, Bond et al. 2019). Only two specimens exist, both in the Natural History Museum, Tring (Knox \& Walters 1994, Bond et al. 2019). On Gough, the Gough Moorhen Gallinula comeri persists, and 2,000-3,000 pairs are found throughout the island (Watkins \& Furness 1986). In 1956, six Gough Moorhens were introduced to Tristan at Sandy Point on the east coast, and they are now present through much of the island including the settlement plain (Richardson 1984). There was considerable debate about whether G. nesiotis had persisted or indeed whether G. nesiotis and G. comeri were the same species (Broekhuysen \& Macnae 1949, Eber 1961). Molecular evidence now indicates that they are indeed separate taxa and that G. nesiotis is extinct (Groenenberg et al. 2008).

The ecology of the Gough Moorhen on Tristan, however, has received scant attention with the only deGallinula nesiotis went extinct in the late $19^{\text {th }}$ century,

TABLE 1. The contents of the proventriculus and gizzard (ventriculus) of four Gough Moorhens Gallinula comeri from Tristan da Cunha. - Körtelmagens (proventriculus) och muskelmagens (ventriculus) innehåll i fyra goughrörhönor Gallinula comeri på Tristan da Cunha.

\begin{tabular}{|c|c|c|c|c|c|c|c|c|}
\hline \multicolumn{3}{|c|}{$\begin{array}{l}\text { Bird characteristics } \\
\text { Fågelegenskaper }\end{array}$} & \multicolumn{5}{|c|}{$\begin{array}{l}\text { Abundance by estimated volume (\%) } \\
\text { Uppskattad mängd som del av total volym (\%) }\end{array}$} & \multirow[b]{2}{*}{ Notes } \\
\hline Bird & Sex & Age & Vegetation & Spider & Earthworm & $\begin{array}{l}\text { House } \\
\text { mouse }\end{array}$ & $\begin{array}{l}\text { Anthropogenic } \\
\text { debris }\end{array}$ & \\
\hline Fågel & Kön & Alder & Vegtation & Spindel & Daggmask & Husmus & Mänskligt avfall & Anmärkningar \\
\hline 1 & 우 & Adult & 100 & 0 & 0 & 0 & Present & $\begin{array}{l}1 \text { piece of metal foil garbage } \\
1 \text { bit metallfolie }\end{array}$ \\
\hline 2 & ㅇ & Adult & 0 & 0 & 0 & Present & 0 & $\begin{array}{l}6 \text { vertebrate bones ( } 3 \text { rodent, } \\
3 \text { unidentified) } \\
6 \text { ben från ryggradsdjur } \\
\text { ( } 3 \text { gnagare, } 3 \text { oidentifierade) }\end{array}$ \\
\hline 3 & $0^{7}$ & Adult & 95 & 5 & Present & 0 & Present & $\begin{array}{l}2 \text { small pieces of glass } \\
2 \text { små glasbitar }\end{array}$ \\
\hline 4 & $?$ & Juvenile & 90 & 5 & 5 & 0 & 0 & \\
\hline
\end{tabular}


tailed information on diet from Richardson (1984) who examined four stomachs in the early 1970s. On Gough Island, the moorhens are predatory scavengers, eating a variety of plants and invertebrates, seabird carrion and eggs, and even introduced house mice Mus musculus (Watkins \& Furness 1986, Wanless \& Wilson 2007). On Tristan, where there are significantly fewer seabirds and more introduced mammals and plants (Wace 1967, Wace \& Holdgate 1976), Richardson (1984) found seeds, vegetation and gravel, but also eggshells and a cephalopod beak in 1973 and 1974. The specimens were deposited in the Natural History Museum, Tring (NHMUK 1984.7.1-4), but contain no further details of diet or stomach contents.

We examined the stomachs of four Gough Moorhens on Tristan da Cunha in the summer of 2014/2015.
Birds were killed accidentally during rodent trapping at Pigbite $(n=2)$ and Big Point Road $(n=2)$ at $270-350 \mathrm{~m}$ elevation. Birds were sexed either by dissection or using measurements (Parker et al. 2012). The complete proventriculus and gizzard were dissected out and flushed with tap water. The contents were examined under a $10-40 \times$ dissecting microscope, and prey identified to the nearest $5 \%$ by volume.

Of the four examined, the stomach of one was empty aside from six small bones, three of which were of house mouse tail vertebrae. The remaining three had consumed predominantly vegetation, likely one of the many endemic or introduced grasses on Tristan (Ryan 2007). Two had also smaller proportions of earthworms and spiders. Two birds had also consumed anthropogenic debris, including metal foil and glass (Table 1).
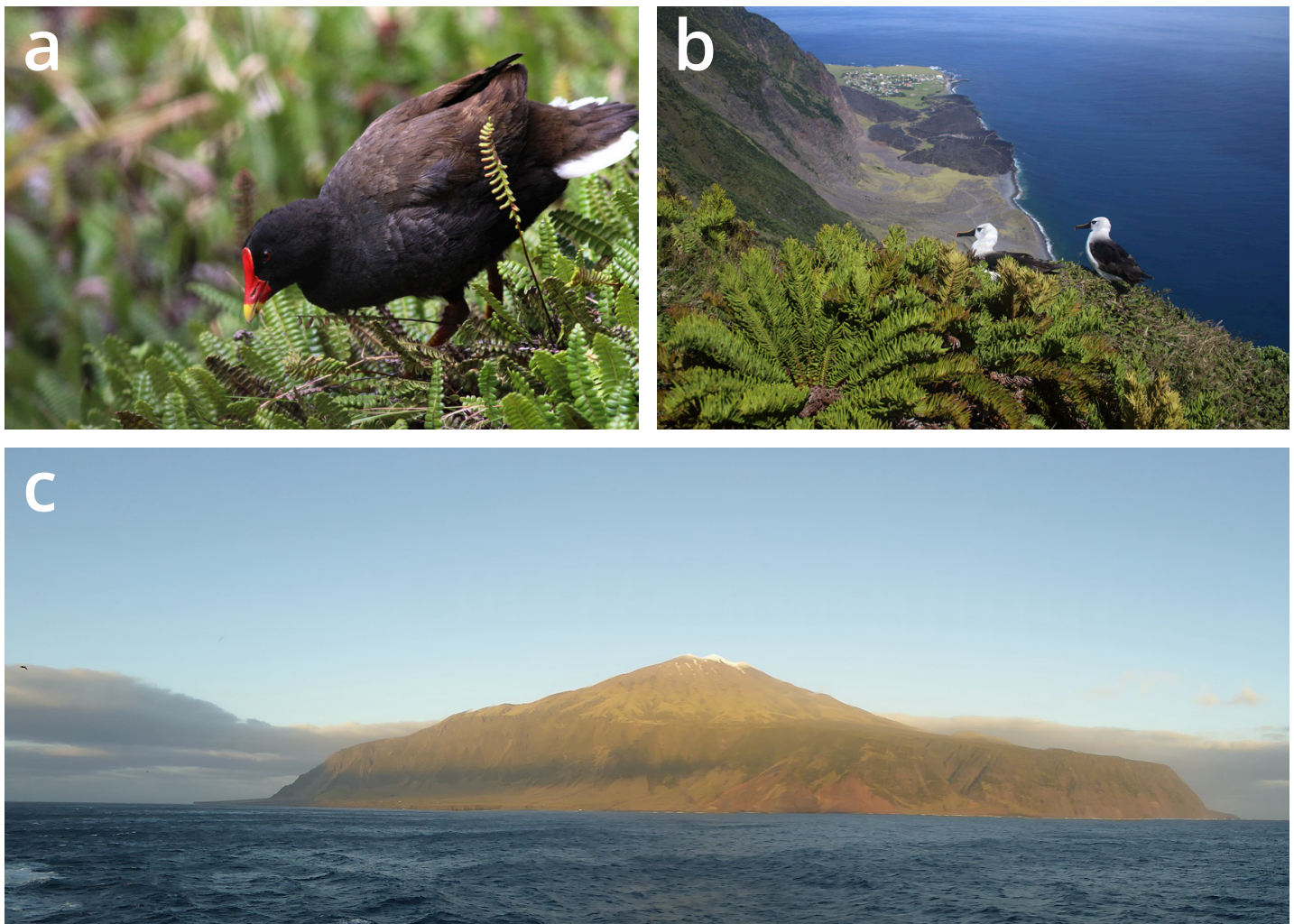

FIGURE 2. (a) Gough Moorhen Gallinula comeri on Tristan, foraging in Blechnum penna-marina (GTWM). (b) View from Pigbite looking northwest towards Edinburgh of the Seven Seas and the Settlement Plain, across a recent lava field. Moorhens occupy all these diverse habitats (GTWM). (c) Tristan as viewed from the sea, with Queen Mary's Peak (2,060 m) and the Settlement Plain on the left (ALB).

- (a) En goughrörhöna Gallinula comeri födosöker bland Blechnum penna-marina på Tristan da Cunha (GTWM). (b) Vy mot nordväst från Pigbite, över ett lavafält mot Edinburgh of the Seven Seas och Settlement Plain (GTWM). (c) Tristan sedd från havet, med Queen Mary's Peak tronande vid $2060 \mathrm{~m}$ höjd och Settlement Plain med bebyggelse till vänster (ALB). 
There are six recorded species of earthworm (Oligochaeta: Lumbricidae) on Tristan da Cunha, all non-native and with a palearctic distribution (Reynolds \& Hänel 2005). The arachnid fauna has not been thoroughly studied, but many islands in the Southern Ocean have endemic species or those associated with South America or the neotropics (Pugh 2004).

That moorhens scavenged or preyed on introduced rodents directly is not surprising, as they do the same on Gough Island where house mice are introduced; they also prey on seabird eggs and chicks (Watkins \& Furness 1986, Wanless \& Wilson 2007). Moorhens not only scavenge dead rodents, but also actively pursue and prey upon them (Wanless \& Wilson 2007). If introduced rodents are ever eradicated from Tristan (Dawson et al. 2015, Holmes et al. 2019), and the moorhen population is to remain, a captive population will be required, as was recommended for Gough Island (Dagleish et al. 2017).

The occurrence of debris (glass and foil) in two of the stomachs is also expected. Waste on Tristan is managed by incineration at a site on the 1961 Volcano east of Edinburgh of the Seven Seas, and incomplete burning or escape from waste management streams is common. In the 1970s, one moorhen had ingested gravel (Richardson 1984), presumably as gastroliths to aid in digestion (Downs et al. 2019). This is the first occurrence of recorded debris ingested by terrestrial birds on Tristan da Cunha, where there is also a significant influx of plastics from international shipping (Ryan et al. 2019). Moorhens are widespread on Tristan, and though uncommon along the coast, can forage on beaches, and likely have territories of c. 5,000 $\mathrm{m}^{2}$ (Watkins \& Furness 1986).

Together, these results confirm that introduced Gough Moorhens on Tristan have similar diets to those on Gough, namely a generalist, but primarily herbivorous one with opportunistic scavenging and possibly direct predation of introduced rodents. Broader ecosystem restoration on Tristan must account for the potential impact on, and of, Gough Moorhens.

\section{Acknowledgements}

We thank the Tristan da Cunha Conservation Department, as well as the Administrator and Island Council for permission to work on Tristan, and for their support during our stay. Comments from anonymous reviewers improved this manuscript.

\section{References}

Angel A \& Cooper BA. 2006. A review of the impacts of introduced rodents on the islands of Tristan da Cunha and Gough. RSPB Research Report No. 17. RSPB, Sandy, UK.

Bond AL, Carlson CJ \& Burgio KR. 2019. Local extinctions of insular avifauna on the most remote inhabited island in the world. Journal of Ornithology 160: 49-6o. https://doi.org/10.1007/ S10336-018-1590-8

Broekhuysen GJ \& Macnae W. 1949. Observations on the birds of Tristan da Cunha Islands and Gough Island in February and early March, 1948. Ardea 37: 97-113.

Caravaggi A, Cuthbert RJ, Ryan PG, Cooper J \& Bond AL. 2019. The impacts of introduced House Mice on the breeding success of nesting seabirds on Gough Island. Ibis 161: 648-661. https://doi. org/10.1111/ibi.12664

Dagleish MP, Ryan PG, Girling S, Ghazali M \& Bond AL. 2017. Clinical pathology of the Vulnerable Gough Moorhen (Gallinula comeri). Journal of Comparative Pathology 157: 246-255. https://doi. org/10.1016/j.jcpa.2017.08.003

Dawson J, Oppel S, Cuthbert RJ, Holmes N, Bird JP, Butchart SHM, Spatz DR \& Tershy B. 2015. Prioritizing islands for the eradication of invasive vertebrates in the United Kingdom Overseas Territories. Conservation Biology 29: 143-153. https://doi.org/10.1111/cobi.12347

Dilley BJ, Davies D, Glass T, Bond AL \& Ryan PG. 2020. Severe impact of introduced scale insects on Island Trees threatens endemic finches at the Tristan da Cunha archipelago. Biological Conservation 251: 108761. https://doi.org/10.1016/j.biocon.2020.108761

Downs CT, Bredin IP \& Wragg PD. 2019. More than eating dirt: a review of avian geophagy. African Zoology 54: 1-19. https://doi.org/ 10.1080/15627020.2019.1570335

Eber G. 1961. Vergleichende untersuchungen am flugfähigen Teichhuhn Gallinula chl. chloropus und an der flugunfaähigen Inselralle Gallinula nesiotis. Bonner Zoologische Beitraege 12: 247-315.

Groenenberg DSJ, Beintema AJ, Dekker RWRJ \& Gittenberger E. 2008. Ancient DNA elucidates the controversy about the flightless island hens (Gallinula sp.) of Tristan da Cunha. PLoS ONE 3: e1835. https://doi.org/10.1371/journal.pone.0001835

Holdgate MW. 1965. The fauna of the Tristan da Cunha islands. Philosophical Transactions of the Royal Society of London B Biological Sciences 249: 361-424. https://doi.org/10.1098/rstb.1965.0015

Holmes ND, Spatz DR, Oppel S, Tershy B, Croll DA, Keitt B, Genovesi P, Burfield IJ, Will DJ, Bond AL, Wegmann A, Aguirre-Muñoz A, Raine AF, Knapp CR, Hung C-H, Wingate D, Hagen E, Méndez-Sánchez F, Rocamora G, Yuan H-W, Fric J, Millett J, Russell J, Liske-Clark J, Vidal E, Jourdan H, Campbell K, Springer K, Swinnerton K, Gibbons-Decherong L, Langrand O, Brooke MdL, McMinn M, Bunbury N, Oliveira N, Sposimo P, Geraldes P, McClelland P, Hodum P, Ryan PG, Borroto-Páez R, Pierce R, Griffiths R, Fisher RN, Wanless R, Pasachnik SA, Cranwell S, Micol T \& Butchart SHM. 2019. Globally important islands where eradicating invasive mammals will benefit highly threatened vertebrates. PLoS ONE 14: e0212128. https://doi.org/10.1371/ journal.pone.0212128

Jones AG, Chown SL, Ryan PG, Gremmen NJM \& Gaston KJ. 2003. A review of conservation threats on Gough Island: a cast stury for terrestrial conservation in the Southern Oceans. Biological Conservation 113: 75-87. https://doi.org/10.1016/Sooo6-3207(02)00351-8 
Knox AG \& Walters M. 1994. Extinct and endangered birds in the collections of the Natural History Museum. British Ornithologists Club Occasional Publications 1. British Ornithologists Club, Tring, UK.

Parker GC, Rexer-Huber K, Parker KA, Ryan PG, Techow NMSM \& Cuthbert RJ. 2012. Morphometric and genetic sexing in the Gough Moorhen Gallinula comeri. Ringing \& Migration 27: 20-25. https:// doi.org/10.1080/03078698.2012.691325

Pugh PJA. 2004. Biogeography of spiders (Araneae: Arachnida) on the islands of the Southern Ocean. Journal of Natural History 38 : 1461-1487. https://doi.org/10.1080/0022293031000155403

Reynolds JW \& Hänel C. 2005. The earthworms (Oligochaeta: Lumbricidae) of Tristan da Cunha and Nightingale Islands, South Atlantic Ocean. Megadrilogica 10: 47-56.

Richardson ME. 1984. Aspects of the ornithology of the Tristan da Cunha group and Gough Island, 1972-1974. Cormorant 12: 123-201.

Ryan PG. 2007. Field guide to the animals and plants of Tristan da Cunha and Gough Island. Pisces Publications, Newbury, UK.

Ryan PG, Dilley BJ, Ronconi RA \& Connan M. 2019. Rapid increase in Asian bottles in the South Atlantic Ocean indicates major debris inputs from ships. Proceedings of the National Academy of Sciences 116: 20892-20897. https://doi.org/10.1073/pnas.1909816116

Ryan PG, Dorse C \& Hilton GM. 2006. The conservation status of the Spectacled Petrel Procellaria conspicillata. Biological Conservation 131: 575-583. https://doi.org/10.1016/j.biocon.2006.03.004 Sperling RM. 1872. Letter. Ibis III/2: 74-79.
Wace NM. 1967. Alien plants in the Tristan da Cunha islands. Pp 46-60 in Toward a new relationship of man and nature in temperate lands. Part III. Changes due to introduced species. IUCN Publications new series No. 9. IUCN, Morges, Switzerland.

Wace NM. 1969. The discovery, exploitation and settlement of the Tristan da Cunha Islands. Proceedings of the Royal Geographical Society of Australia, South Australian Branch 70: 11-40.

Wace NM \& Dickson JH. 1965. Part II. The terrestrial botany of the Tristan da Cunha Islands. Proceedings of the Royal Society of London B Biological Sciences 49: 273-36o. https://doi.org/10.1098/ rstb.1965.0014

Wace NM \& Holdgate MW. 1958. The vegetation of Tristan da Cunha. Journal of Ecology 46: 593-620. https://doi.org/10.2307/2257541

Wace NM \& Holdgate MW. 1976. Man and nature in the Tristan da Cunha islands. IUCN Monograph 6. IUCN, Morges, Switzerland.

Wanless RM, Ryan PG, Altwegg R, Angel A, Cooper J, Cuthbert RJ \& Hilton GM. 2009. From both sides: Dire demographic consequences of carnivorous mice and longlining for the Critically Endangered Tristan albatrosses on Gough Island. Biological Conservation 142: 1710-1718. https://doi.org/10.1016/j.biocon.2009.03.008

Wanless RM \& Wilson JW. 2007. Predatory behaviour of the Gough Moorhen Gallinula comeri: conservation implications. Ardea 95: 311-315.

Watkins BP \& Furness RW. 1986. Population status, breeding and conservation of the Gough Moorhen. Ostrich 57: 32-36. https://doi. org/10.1080/00306525.1986.9633636

\section{Svensk sammanfattning}

Ögruppen Tristan da Cunha - som utöver huvudön inkluderar Nightingale Island och Inaccessible Island - samt Gough Island är en av jordens mest isolerade platser, belägen i södra Atlanten mellan Afrika och Sydamerika (figur 1). Fågelfaunan har stort inslag av endemiska arter, vilken sedan koloniseringen av öarna under tidigt 180o-tal och efterföljande introduktion av invasiva arter och predatorer påverkats starkt negativt. På Tristan och Gough fanns ursprungligen flygoförmögna rörhönor, men på Tristan utrotades dessa under slutet av 1800-talet, troligen av en kombination av jakt och predation från katt. På grannön Gough fanns dock fåglarna kvar och idag är populationen runt 2000-3000 par. Mer sentida studier har visat att det rörde sig om två olika arter på de båda öarna: tristanrörhöna Gallinula nesiotus respektive goughrörhöna G. comeri. År 1956 flyttades sex goughrörhönor till huvudön Tristan och dessa har lyckats etablera en population (figur 2).

Goughrörhönans ekologi på Tristan är dåligt känd, men från Gough vet man att de kan ha en bred diet som inkluderar växtdelar, olika ryggradslösa djur, as från sjöfågel, ägg och till och med möss (introducerade Mus musculus). Ön Tristan har färre häckande havsfåglar än Gough, och fler introducerade däggdjur och växter, vilket gör det troligt att födan skiljer sig mellan öarna. I samband med studier på invasiva gnagare på Tristan 2014-2015 fångades fyra goughrörhönor oavsiktligt, vilkas maginnehåll studerades.

Av de fyra undersökta fåglarna hade en fågel en relativt tom mage, som endast innehöll sex små benrester varav tre kunde härledas till svanskotor från möss. De tre andra fåglarna hade mestadels ätit vegetabilier, mest troligt ett av de endemiska eller introducerade grässlagen. Två av magarna innehöll en mindre andel daggmaskar och spindlar och två av fåglarna hade konsumerat skräp i form av aluminiumfolie och glas (tabell 1). Dieten antyder att goughrörhönorna har en generalistisk, allätande strategi på Tristan och inte drar sig från att predera även större djur som möss, eller ägg. På Tristan drivs en kampanj för att utrota introducerade gnagare och det återstår att se hur detta påverkar fågelfaunan. Ett förslag som diskuterats är att bibehålla 
en inhägnad population goughrörhönor som försäkring ifall den vilda påverkas ytterligare negativt.

Att fåglarna konsumerat skräp kan tyckas förvånande, men faktum är att sophantering mestadels har skett genom enkel förbränning på ön, från vilken skräp kan transporteras via vatten eller vind till andra delar av ön.

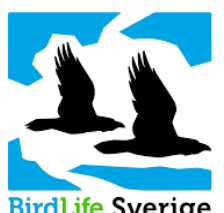

BirdLife Sverige

Ornis Svecica (ISSN 2003-2633) is an open access, peer-reviewed scientific journal published in English and Swedish by BirdLife Sweden. It covers all aspects of ornithology, and welcomes contributions from scientists as well as non-professional ornithologists. Accepted articles are published at no charge to the authors. Read papers or make a submission at os.birdlife.se.

Ornis Svecica (ISSN 2003-2633) är en fritt tillgänglig granskad vetenskaplig tidskrift som ges ut på svenska och engelska av BirdLife Sverige. Den täcker ornitologins alla områden och välkomnar bidrag från såväl forskare som icke-professionella ornitologer. Accepterade uppsatser publiceras utan kostnad för författarna. Läs uppsatser eller skicka in ditt bidrag på os.birdlife.se. 